\title{
Ceratozamia aurantiaca (Zamiaceae): A New Cycad Species from the Northern Rainforests of Oaxaca, Mexico
}

\author{
Miguel Angel Pérez-Farrera ${ }^{1,2, *}$, José Said Gutiérrez-Ortega ${ }^{3, *} \mathbb{C}$, Jody L. Haynes ${ }^{4} \mathbb{C}$, Jeff Chemnick ${ }^{5}$, \\ Silvia H. Salas-Morales ${ }^{6}$, Michael Calonje ${ }^{7}\left(\mathbb{B}\right.$ and Andrew P. Vovides ${ }^{8}[\mathbb{C}$
}

1 Laboratorio de Ecología Evolutiva, Herbario Eizi Matuda, Instituto de Ciencias Biológicas, Universidad de Ciencias y Artes de Chiapas, Tuxtla Gutiérrez 29039, Mexico

2 Facultad de Ciencias Naturales, Universidad Autónoma de Querétaro, Ave. De las Ciencias s/n, Juriquilla, Santa Rosa Jáuregui, Querétaro 76230, Mexico

3 Institute for Excellence in Educational Innovation, Chiba University, Chiba 263-8522, Japan

4 Fairchild Tropical Botanic Garden, Coral Gables, FL 33156, USA; jody@cycadconservation.org

5 Ganna Walska Lotusland, Santa Barbara, CA 93108, USA; jeffchemnick@cox.net

6 Sociedad para el Estudio de los Recursos Bióticos de Oaxaca, San Sebastián Tutla, Oaxaca 71246, Mexico; sschibli@hotmail.com

7 Montgomery Botanical Center, Coral Gables, FL 33156, USA; michaelc@montgomerybotanical.org

8 Red de Biología Evolutiva, Instituto de Ecología, A.C., Xalapa 91070, Mexico; andrew.vovides@inecol.mx

* Correspondence: perezfarreram@gmail.com (M.A.P.-F.); josesgo@gmail.com (J.S.G.-O.)

check for

updates

Citation: Pérez-Farrera, M.A.; Gutiérrez-Ortega, J.S.; Haynes, J.L.; Chemnick, J.; Salas-Morales, S.H.;

Calonje, M.; Vovides, A.P. Ceratozamia aurantiaca (Zamiaceae): A New Cycad Species from the Northern Rainforests of Oaxaca, Mexico. Taxonomy 2021, 1, 243-255. https:// doi.org/10.3390/taxonomy1030018

Academic Editor: Xian-Chun Zhang

Received: 4 August 2021

Accepted: 18 August 2021

Published: 19 August 2021

Publisher's Note: MDPI stays neutral with regard to jurisdictional claims in published maps and institutional affiliations.

Copyright: (c) 2021 by the authors. Licensee MDPI, Basel, Switzerland. This article is an open access article distributed under the terms and conditions of the Creative Commons Attribution (CC BY) license (https:// creativecommons.org/licenses/by/ $4.0 /)$.

\begin{abstract}
Ceratozamia aurantiaca, a new cycad species from Oaxaca, Mexico, is described. The new species is endemic to lowland karst tropical rainforests of the northern mountains (Sierra Norte region). This species is related to C. subroseophylla and C. robusta, together considered part of the C. robusta species complex due to their shared characteristics: robust, upright trunk; large and long leaves with densely armed petioles and linear to subfalcate leaflets; and large megastrobili. Ceratozamia aurantiaca, as the epithet suggests, is easily distinguished from other species by the orange color of its emerging leaves, a trait unique in the genus. Additionally, C. aurantiaca is distinguished from C. subroseophylla and C. robusta by having significantly shorter petioles, wider spacing between leaflets, and wider median leaflets. The taxonomic recognition of this species represents a step toward clarifying species delimitation in the C. robusta complex.
\end{abstract}

Keywords: cycads; botanic gardens; endangered species; morphological analyses; new species; Mexico

\section{Introduction}

The cycad genus Ceratozamia Brongn. (Zamiaceae) currently comprises 33 species from Mexico, Guatemala, Belize, and Honduras, with all but three endemic to Mexico [1]. Most species are represented by one to a few narrowly distributed populations separated by a few to several kilometers, generally inhabiting tropical evergreen forest, oak forest, or tropical montane cloud forest [2]. In Ceratozamia, species that are closely related phylogenetically also tend to exhibit geographic proximity and similar morphology [3], which are criteria considered as proxy when testing species delimitation. The species definition within the genus has traditionally been based on morpho-geographic criteria, such that each species is represented by one or more geographically close populations that share morphological characteristics $[4,5]$. Even so, species delimitation among closely related species has been a constant challenge in Ceratozamia [2,6,7].

Recent reviews of the genus have proposed the recognition of species complexes, which are groups of species with high morphological resemblance [2,8]. Belonging to a species complex in Ceratozamia implies that it can be difficult to correctly identify a member taxon within the complex if detailed information about its origin in the wild is unknown. The C. robusta species complex has been considered one of the most taxonomically difficult groups in the genus [2] (Figure 1). Plants belonging to this species complex are easily 
recognized by their robust epigeous trunks, large robust cones, large leaves, and petioles that are densely armed with prickles - a set of traits distinct in the genus. Increased interest in cycads in the late 20th century led to the discovery of populations of C. robusta Miq. in the states of Chiapas, Oaxaca, and Veracruz (Mexico), as well as in Guatemala and Belize (Figure 1). Although all populations from these regions share the aforementioned suite of morphological characteristics, a high level of variation among populations of C. robusta sensu lato was previously noted [5] and has only been carefully examined in recent years $[7,9,10]$.

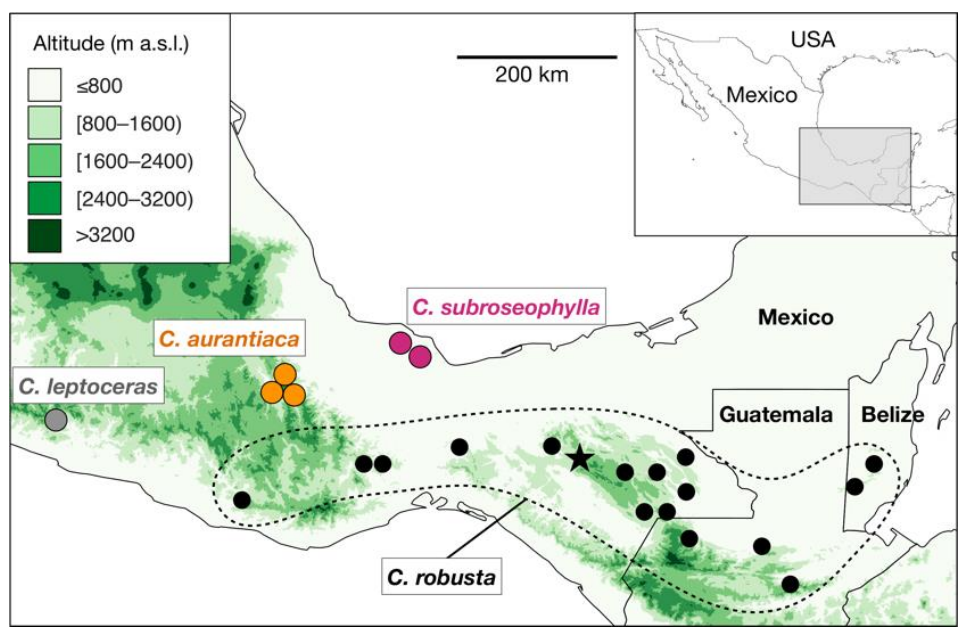

Figure 1. Distribution map of the known populations of Ceratozamia robusta species complex. Black circles surrounded by a dotted line indicate the occurrence of populations of C. robusta, as currently circumscribed. The star symbol indicates the neotype locality of C. robusta (Parque Nacional Cañón del Sumidero, Chiapas, Mexico). Ceratozamia subroseophylla, previously considered as C. robusta, has been recorded in two areas in Santiago Tuxtla, Veracruz, Mexico. The putative new species (herein named Ceratozamia aurantiaca; see results) occurs in two localities in the Sierra Norte region, Oaxaca, Mexico; these populations have been long considered as C. robusta. Green color scale indicates the elevation in meters above sea level (m a.s.l.) as recorded in the raster layers of 30-s resolution of the NASA Shuttle Radar Topographic Mission (SRTM) 90 m Digital Elevation Database v4.1 deposited in DIVA-GIS (https: / /www.diva-gis.org/, accessed on 15 July 2021).

Martínez-Domínguez et al. [7] (2016) demonstrated that populations from the Los Tuxtlas region of Veracruz, historically recognized as Ceratozamia robusta, were significantly differentiated from other populations of C. robusta. The authors used qualitative morphological traits and molecular evidence to support the erection of a new species that they named C. subroseophylla Mart.-Domínguez \& Nic.-Mor. In a similar way, populations from Guerrero (Mexico) reportedly closely related to C. robusta were assigned to a new taxon, C. leptoceras Mart.-Domínguez, Nic-Mor., D.W. Stev. \& Lorea-Hern. [9]. Close inspection of morphological variation among populations in Chiapas (Mexico) and Belize revealed that the populations from the Chiapas Highlands (Los Altos de Chiapas), historically recognized as C. robusta, represented yet another different species, C. sanchezae Pérez-Farr., Gut.Ortega \& Vovides [10], which has a closer morphological resemblance to the C. miqueliana species complex than to $C$. robusta. These studies showed that detailed observations and statistical testing of the morphological variation among populations can be used to delimit species within the C. robusta species complex.

In the 1970s, a Ceratozamia population that was considered to be either C. mexicana Brongn., C. mexicana var. robusta (Miq.) Dyer, or C. robusta (according to determinations on herbarium specimens deposited in MEXU, SERO, and HEM), was discovered near the hydroelectric dam "Presa Miguel Alemán" in the Sierra Norte region of Oaxaca (Mexico). Living plants from an early collection at this location, characterized by orange emerging leaves, were introduced into horticulture in the USA, almost exclusively in Florida. The 
taxon remains in cultivation today, where it is informally known as Ceratozamia sp. "Presa Alemán". The original locality where the plants were collected was subsequently submerged under the waters of the reservoir upon completion, and accordingly, the taxon was believed to have been rendered extinct. However, further exploration in adjacent areas not affected by the flooding of the Presa Alemán in 2000 resulted in the discovery of more populations with the distinctive orange emergent leaves. In consideration of these new plant records, botanists regarded these populations from the Sierra Norte region as belonging to the C. robusta species complex [2,5] due to their robust trunks, large cones, and large leaves with petioles densely armed with prickles. Observations of plants in situ revealed that they all produce leaves that emerge brown and quickly change to orange (Figure 2). This same coloration occurs ex situ, in a plant cultivated for nearly 30 years at Fairchild Tropical Botanic Garden (FTBG) in Florida, USA, suggesting that this distinctive trait is intrinsic and not due to environmental conditions (Figures A1 and A2). This observation led to the question of whether this population represented a subset of the intraspecific variation of the widely distributed C. robusta or a distinct species that should be recognized taxonomically.
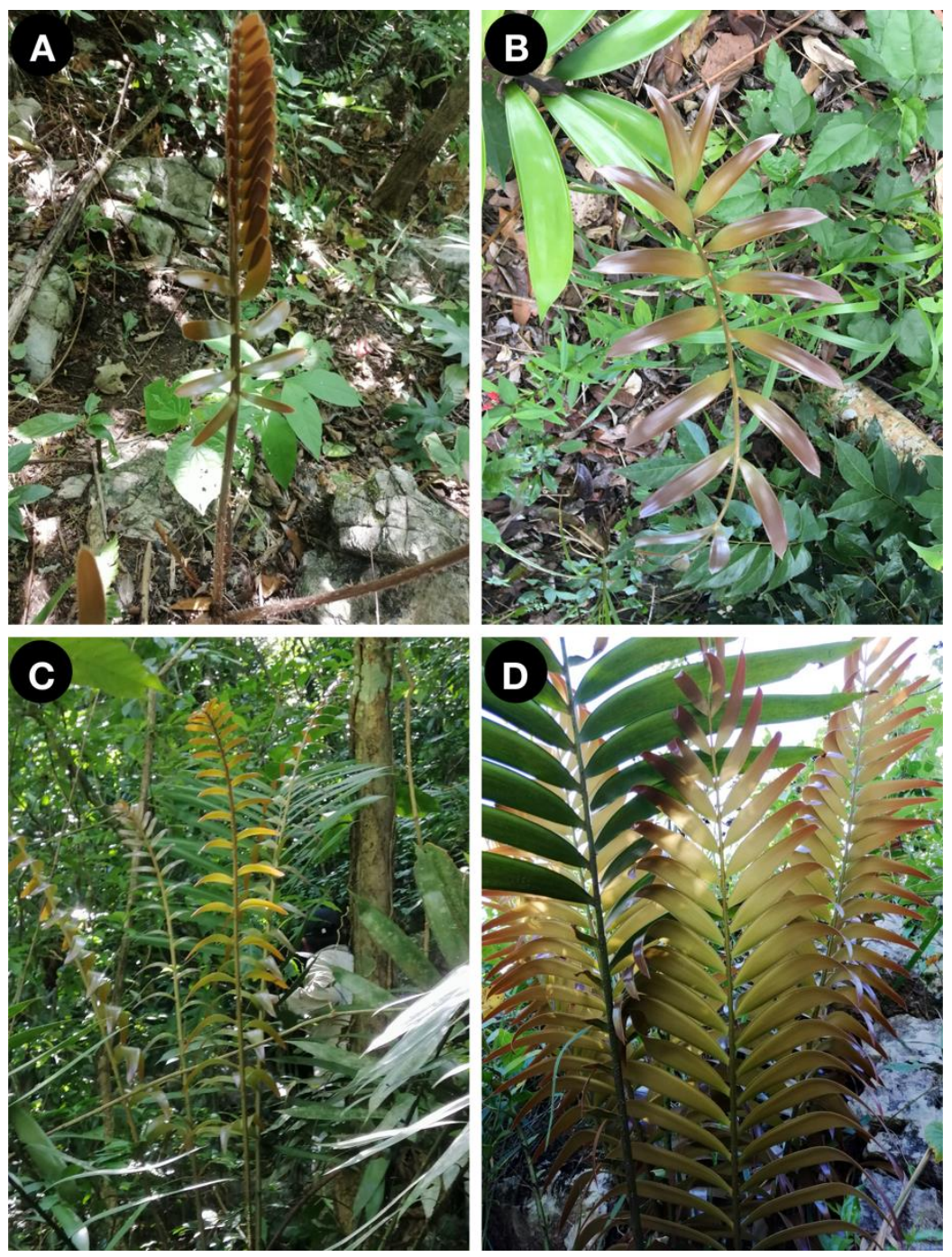

Figure 2. Emerging leaf color in a Ceratozamia aurantiaca sp. nov. population from San Pedro Teutila, Sierra Norte region, Oaxaca (Mexico). The orange-brown color occurs early in emergence and appears in juveniles (A,B) and adults (C,D). 


\section{Materials and Methods}

Morphological variation of 16 adult plants was observed in a population near San Pedro Teutila in the Sierra Norte region, Oaxaca, Mexico, and compared with the variation within the two closest morphological species: C. robusta and C. subroseophylla (Table 1). For C. robusta, plants were examined in the neotype population (San Fernando, Parque Nacional Cañón del Sumidero, Chiapas, Mexico), and for C. subroseophylla, the type population from Santiago Tuxtla, Veracruz, was assessed. Qualitative traits were also observed to identify differences among the three species (Table 2). Ceratozamia leptoceras has been suggested by some workers to be closely related to C. robusta [9], and it was compared to the other three species using qualitative data from its original description.

Table 1. Species and population locations compared in this study. $n=$ number of samples analyzed in morphometric analyses.

\begin{tabular}{|c|c|c|c|}
\hline Species & $\begin{array}{l}\text { Elevation } \\
\text { (m a.s.1.) }\end{array}$ & Locality & $n$ \\
\hline C. aurantiaca & 480 & Teutila, Sierra Norte region, Oaxaca, Mexico & 16 \\
\hline C. robusta & 1200 & $\begin{array}{c}\text { San Fernando, Parque Nacional Cañón del } \\
\text { Sumidero, Chiapas, Mexico (neotype population) }\end{array}$ & 20 \\
\hline C. subroseophylla & 500 & $\begin{array}{c}\text { Santiago Tuxtla, Veracruz, Mexico } \\
\text { (type population) }\end{array}$ & 11 \\
\hline
\end{tabular}

Table 2. Comparison of morphological variation among species of the Ceratozamia robusta complex.

\begin{tabular}{ccccc}
\hline Trait & C. aurantiaca & C. subroseophylla & C. leptoceras & C. robusta \\
\hline Trunk & Erect to decumbent & Erect to decumbent & Erect to decumbent & Erect \\
Color of emerging leaves & $\begin{array}{c}\text { Orange-brown to } \\
\text { orange }\end{array}$ & Yellowish-brown & Green to copper-green & Reddish-brown \\
Crown of leaves & Open & Open & Open & Closed \\
Texture of leaflets & Coriaceous & Papyraceous & Membranaceous & Papyraceous \\
Veins on abaxial surface & Not visible & Visible & Visible & Not visible \\
of leaflets & Mucronate & Mucronate & Acute & Acuminate \\
\hline Apex of female cone & & & Mcumate
\end{tabular}

Seven vegetative traits were measured in adult plants (Table 3). These traits were selected because they have been found to be the most effective with regard to species delimitation in Ceratozamia [10,11]. After transforming values to Z-scores, univariate and multivariate analyses were conducted in Past v3.4 [12]. ANOVA was used to test whether the overall mean variation of the seven traits was differentiated among the three species. Pairwise Tukey's $Q$ was estimated to identify how each trait variation is grouped between the three species. The $p$-values were estimated from a Tukey's Honest Significance test. A Linear Discriminant Analysis (LDA) was used to summarize the total variation of the seven morphometric traits and estimate the overlap among individuals of the three examined species. Finally, the squared Mahalanobis distances among the three groups were calculated to test whether the morphological variation is completely sorted.

Table 3. Morphometric differentiation of seven traits among the three Ceratozamia species examined. Overall differentiation estimated as Welch's $F$ in ANOVA is indicated. d.f = degrees of freedom. Bold $F$ values indicate significant values, with $p<0.05$. The linear discriminant (LD) axis load value of the main axis (which explains $87.79 \%$ of the total variation), as estimated in the LD analysis, is annotated. The three highest absolute LD load values of axis 1 are indicated in bold.

\begin{tabular}{cccccc}
\hline Key & Name Variable and Unit & $\boldsymbol{F}$ & d.f. & $p$ & LD Axis Load \\
\hline A & Length of petiole $(\mathrm{cm})$ & $\mathbf{1 8 . 2 7}$ & 24.93 & $1.30 \times 10^{-5}$ & $\mathbf{0 . 3 0 9}$ \\
B & Length of rachis $(\mathrm{cm})$ & 0.503 & 23.15 & 0.6112 & -0.024 \\
C & Number of leaflet pairs & $\mathbf{1 2 . 5 3}$ & 24.81 & 0.0001735 & 0.103 \\
D & Length of median leaflets (mm) & 1.682 & 21.84 & 0.2092 & 0.032 \\
\hline
\end{tabular}


Table 3. Cont.

\begin{tabular}{cccccc}
\hline Key & Name Variable and Unit & $\boldsymbol{F}$ & d.f. & $p$ & LD Axis Load \\
\hline E & Distance between median leaflets $(\mathrm{mm})$ & $\mathbf{1 2 . 5 6}$ & 23.87 & 0.0001877 & $-\mathbf{0 . 2 7 8}$ \\
F & Width of median (mm) & $\mathbf{2 0 . 9 4}$ & 24.59 & $4.899 \times 10^{-6}$ & $-\mathbf{0 . 2 2 7}$ \\
G & Width of basal leaflets (mm) & $\mathbf{7 . 2 7 7}$ & 22.46 & 0.003662 & -0.033 \\
\hline
\end{tabular}

\section{Results}

\subsection{Morphological Observations}

Several qualitative traits were identified as exclusive to the putative new species (Table 2). As previously noted in wild plants and botanical garden collections, the orange color of emerging leaves is the most conspicuous unique trait for the plants from the Sierra Norte region, Oaxaca, but it is not the only distinctive trait. In the wild, the trunks of these plants grow erect to decumbent, similarly to $C$. subroseophylla, whereas they are always erect in C. robusta. Additionally, the texture of leaflets is coriaceous, but papyraceous in the other two species. Other traits observed in the putative new species are shared with either C. robusta or C. subroseophylla: the veins on the abaxial side of the leaflets are not visible in either the putative new species or C. robusta, but are visible in C. subroseophylla, and the apex of the female cone is mucronate in both the putative new species and C. subroseophylla, but acuminate in C. robusta.

\subsection{Morphometric Analyses}

Five of seven measured morphometric traits were found to be significantly differentiated among the three groups at the overall level: length of petiole, number of leaflets, distance between median leaflets, and width of median and basal leaflets (Table 3). The pairwise comparisons allowed the identification of the traits that are significantly differentiated between the putative new species and the two compared species (Table 4). The putative new species has significantly shorter petioles than both C. robusta and C. subroseophylla (Figure 3A), significantly fewer leaflets than C. subroseophylla (Figure 3C), significantly wider spaces between median leaflets than C. robusta and C. subroseophylla (Figure 3E), significantly wider median leaflets than C. robusta and C. subroseophylla (Figure 3F), and significantly wider basal leaflets than C. robusta (Figure 3G). There are no significant differences among groups in length of rachis (Figure 3B) or length of median leaflets (Figure 3D).

The LDA summarized the total morphometric variation into two main axes, explaining $87.79 \%$ and $12.21 \%$ of the total variation, respectively (Figure 4 ). Three trait groups were found to be completely non-overlapping, as denoted by the biplots in Figure 4 (load values are listed in Table 3): petiole length (trait A), number of leaflets (trait C), and space between median leaflets (trait E). The confusion matrix obtained from the LDA (Table 5) shows that most individuals were estimated to belong to their given groups, as expected; only one individual of the putative new species might be confused with C. robusta, and only two individuals of $C$. robusta might be confused with the putative new species. However, the Mahalanobis distances among the three groups were estimated to be highly significant (Table 6), suggesting that the total variation completely sorted between the assigned groups. 

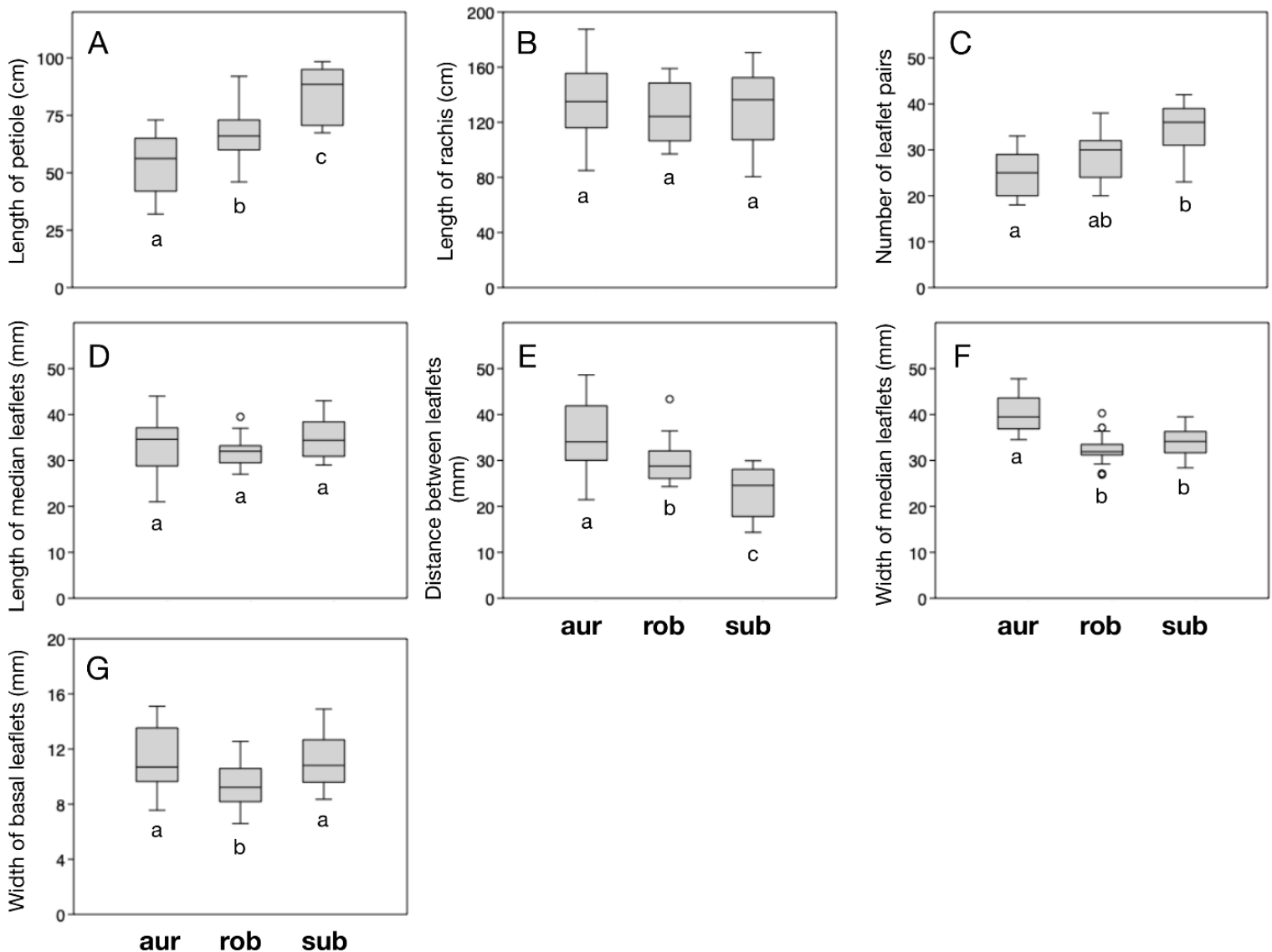

aur rob sub

aur rob sub

Figure 3. Morphometric variation among the three compared species: Ceratozamia aurantiaca (aur), C. robusta (rob), and C. subroseophylla (sub). The order of plots corresponds to the traits (A-G) listed in Table 3. Whiskers indicate standard errors and circles indicate outliers. Different lowercase letters below the bars indicate significant differentiation as estimated in the Tukey's pairwise test (numerical values in Table 4).

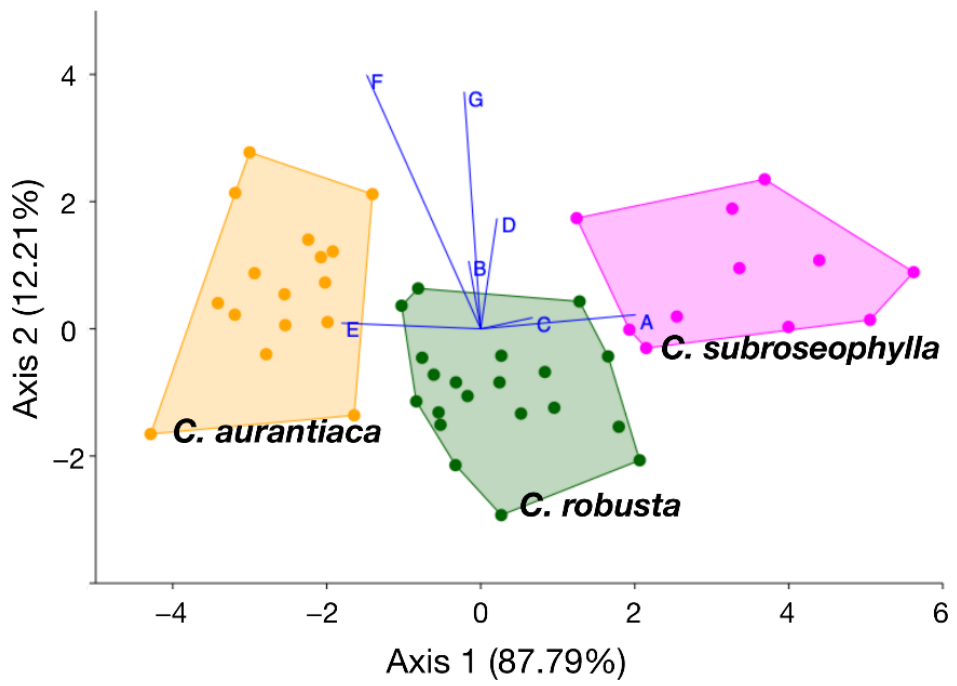

Figure 4. Linear discriminant analysis plot showing the dispersion of the samples of three compared species along the two main axes. Biplots A-F indicate the direction and relative loading score of each trait variation along the two axes. Traits A-G correspond to those listed in Table 3: A, length of petiole; $B$, length of rachis; $C$, number of leaflet pairs; D, length of median leaflets; E, distance between median leaflets; F, width of median leaflets; G, width of basal leaflets. 
Table 4. Pairwise Tukey's Q values of differentiation between species of seven morphometric traits. Abbreviations: traits A-G correspond to those listed in Table $3 .{ }^{*}=p<0.05,{ }^{* *}=p<0.005,{ }^{* * *}=p<0.001$.

\begin{tabular}{cccc}
\hline & $\begin{array}{c}\text { C. aurantiaca vs. } \\
\text { C. robusta }\end{array}$ & $\begin{array}{c}\text { C. aurantiaca vs. } \\
\text { C. subroseophylla }\end{array}$ & $\begin{array}{c}\text { C. subroseophylla vs. } \\
\text { C. robusta }\end{array}$ \\
\hline A (length of petiole) & $4.121^{*}$ & $9.492^{* * *}$ & $5.371^{* *}$ \\
B (length of rachis) & 1.247 & 0.4368 & 0.8097 \\
C (number of leaflet pairs) & 3.066 & $7.815^{* * *}$ & $4.749^{* *}$ \\
D (length of median leaflets) & $1.317^{*}$ & 0.927 & $2.244^{*}$ \\
E (distance between median leaflets) & $3.804^{*}$ & $7.942^{* *}$ & $4.138^{*}$ \\
F (width of median leaflets) & $8.635^{* * *}$ & $6.692^{* * *}$ & $1.942^{*}$ \\
G (width of basal leaflets) & $4.287^{*}$ & 0.4224 & $3.864^{*}$ \\
\hline
\end{tabular}

Table 5. Confusion matrix constructed with the linear discriminant analysis (LDA). Rows indicate given groups (number of individuals considered Ceratozamia aurantiaca, C. robusta, or C. subroseophylla according to their population type) and columns indicate groups predicted by the LDA.

\begin{tabular}{ccccc}
\hline & C. aurantiaca & C. robusta & C. subroseophylla & Total \\
\hline C. aurantiaca & 15 & 1 & 0 & 16 \\
C. robusta & 2 & 18 & 0 & 20 \\
C. subroseophylla & 0 & 0 & 11 & 11 \\
Total & 17 & 19 & 11 & 47 \\
\hline
\end{tabular}

Table 6. Squared Mahalanobis distances (below diagonal) and $p$-values (above diagonal) among the three analyzed species. All values are significant $(p<0.001)$, suggesting complete sorting among species' variation.

\begin{tabular}{cccc}
\hline & C. aurantiaca & C. robusta & C. subroseophylla \\
\hline C. aurantiaca & - & $5.07 \times 10^{-6}$ & $7.42 \times 10^{-8}$ \\
C. robusta & 10.26 & - & $1.80 \times 10^{-5}$ \\
C. subroseophylla & 7.35 .56 & 13.32 & - \\
\hline
\end{tabular}

In summary, the following evidence is presented to support the putative new species described herein: (1) Distinctive qualitative morphological traits distinguish the populations of the Sierra Norte region from C. robusta and C. subroseophylla, the two most closely related taxa. The main distinctive trait is the orange color of emerging leaves (Figure 2). This characteristic can also be observed in plants in cultivation (Figure A1), discarding the alternative explanation that it is due to environmental factors. (2) Significant morphometric differentiation in most of the examined traits distinguishes the populations of the Sierra Norte region from other species in the C. robusta species complex.

\subsection{New Species Description}

Ceratozamia aurantiaca Pérez-Farr., Gut.-Ortega, J.L.Haynes \& Vovides sp. nov. (Figures 5-7).

Holotype:-MEXICO. Oaxaca, Sierra Norte, San Pedro Teutila, 30 May 2021, PérezFarrera M.A \& Díaz-Jiménez p. 4014 o (HEM!). Isotypes: (XAL).

Ceratozamia aurantiaca is easily distinguished by its emerging leaves of orange color that turn green at maturity. It resembles C. robusta, but has longer petioles and wider separation between leaflets along the rachis. 

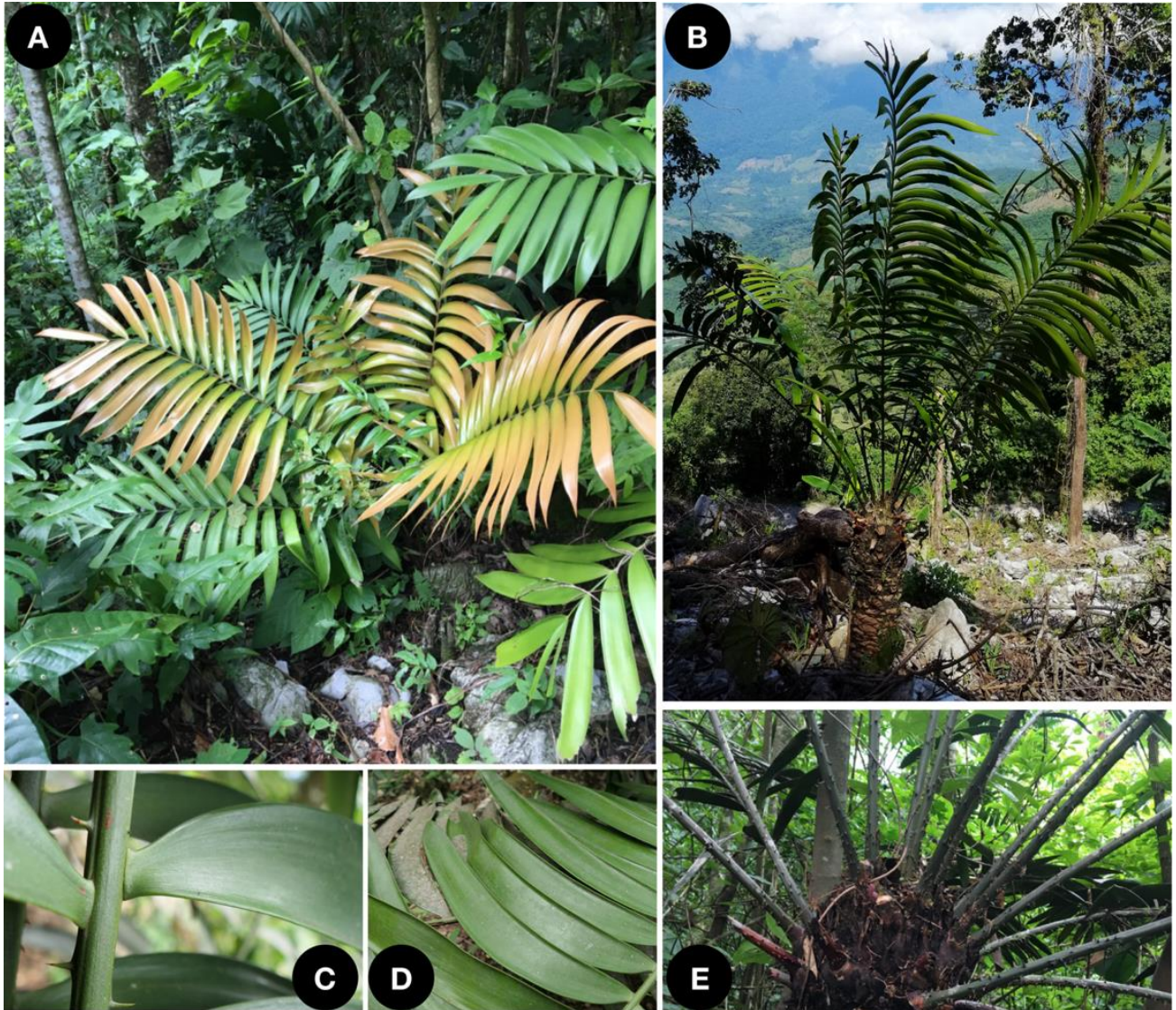

Figure 5. Ceratozamia aurantiaca sp. nov. (A) Adult plant with orange emerging leaves beginning to transition to green. (B) Adult plant with erect trunk. (C,D) Details of leaflet articulation, prickles, and leaflet shape. (E) Details of apex and heavily armed petioles.

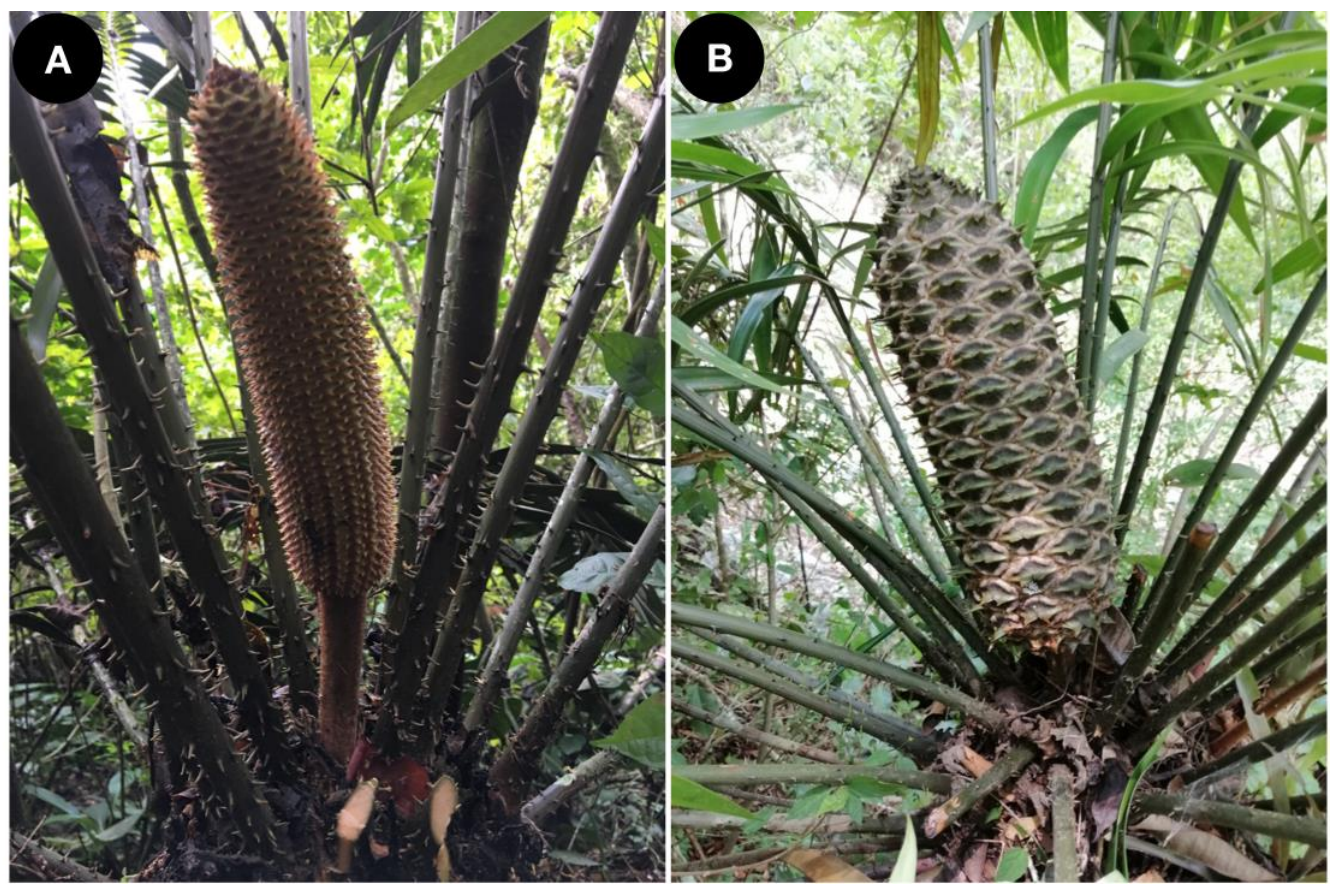

Figure 6. Strobili of Ceratozamia aurantiaca sp. nov. (A) Microstrobilus; (B) megastrobilus. 


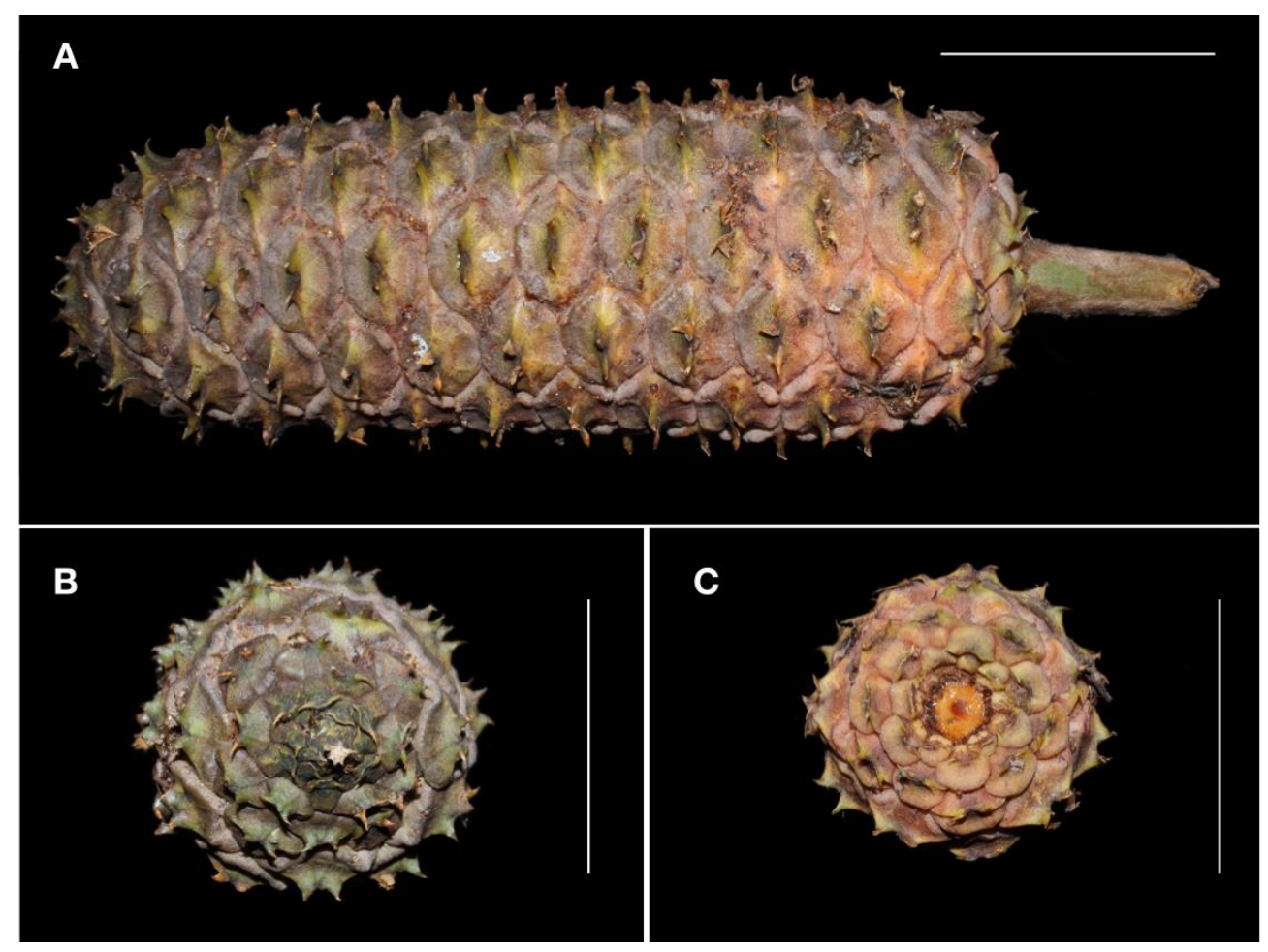

Figure 7. Mature megastrobilus of Ceratozamia aurantiaca sp. nov., showing details of megasporophylls and peduncle (A), mucronate apex (B) and view from below (C). Scale $=10 \mathrm{~cm}$. Photos by José García.

Additional specimens examined:-MEXICO. Oaxaca: Santa Maria Tlalixtac, $675 \mathrm{~m}$ a.s.l. (above sea level), 26 November 2004, Gonzalo Juárez García \& Cutberto Ángel Cruz Espinosa 868 (MEXU, SERO); Chiquihuitlán de Benito Juárez, $861 \mathrm{~m}$ a.s.l., 26 November 2004, Cutberto Ángel Cruz Espinosa \& Gonzalo Juárez García 1945 (MEXU, SERO); San Pedro Teutila, 708 m a.s.l., 10 June 2004, Gonzalo Juárez García \& Laura Escobar 425 (MEXU, SERO); 588 m a.s.l., 30 May 2021, Miguel Ángel Pérez-Farrera \& Pedro Díaz-Jiménez 34,015 $O^{7}$ (MEXU; HEM).

Plant rupicolous, arborescent, unbranching. Stem cylindrical, erect, sometimes decumbent with age, $20-150 \mathrm{~cm}$ tall, $10-15 \mathrm{~cm}$ in diameter, covered with persistent leaf bases. Cataphylls persistent, triangular, brown, densely tomentose at emergence, apex acuminate. Leaves pinnate, $10-27$ per apex (mean = 15), crown open, erect, ascending, eventually arching at maturity, basally slightly keeled, $117-257 \mathrm{~cm}$ long, $53-77 \mathrm{~cm}$ wide, reddish-light brown at emergence, becoming bright orange, and then green at maturity. Petiole terete $31-73 \mathrm{~cm}$ long $($ mean $=54 \mathrm{~cm})$, densely armed with thick prickles. Rachis terete, $85-187$ $\mathrm{cm}$ long $($ mean $=135 \mathrm{~cm})$, with spaced prickles diminishing apically, green at maturity. Leaflets coriaceous, linear to subfalcate, occasionally sigmoid, 19-31 pairs (mean $=25)$, subopposite basally, opposite medially, margin entire, apex asymmetric, acute to acuminate; base broad attenuate, articulation brownish to green, depending on age; veins 29-37, parallel, inconspicuous, slightly translucent; median leaflets $21-38 \mathrm{~cm}$ long (mean $=33 \mathrm{~cm}$ ), $3.4-4.7 \mathrm{~cm}$ wide $($ mean $=4.0 \mathrm{~cm}), 2.4-4.7 \mathrm{~cm}$ between leaflets $($ mean $=3.5 \mathrm{~cm})$, articulation $0.75-1.5 \mathrm{~cm}$ wide $($ mean $=1.0 \mathrm{~cm}$ ). Microstrobilus solitary, cylindrical, erect, $34-36 \mathrm{~cm}$ long, 4-6 cm diameter, light-orange and tomentose when emerging, light brown when mature, peduncle $4.5-7.5 \mathrm{~cm}$ long, 1.2-1.9 cm diameter, densely tomentose. Microsporophyll cuneiform, distal face bicornate, $16-25 \mathrm{~mm}$ long, $7-13 \mathrm{~mm}$ wide, sporangia zone on abaxial surface 11-20 mm long, microsporangia grouped in sori of 3-4. Megastrobilus solitary, cylindrical, erect, 39-42 cm long, 10.3-10.7 cm diameter, light-orange pubescent base color with green diamond-shaped patches and dark brown trichomes on megasporophyll terminal facets at emergence, maturing light-orange with greenish-yellow horizontal line and 
brown trichomes on megasporophyll terminal facets; apex mucronate, peduncle 7-8.8 cm long, $1.8-1.9 \mathrm{~cm}$ in diameter, tomentose. Megasphorophylls peltate, bicornate, $3-4.25 \mathrm{~cm}$ wide, 1.7-2.4 cm tall, distal face pubescent, brown to reddish-orange (including horns) at maturity, base green with light-orange pubescence; peduncle tomentose, light green when immature, light brown at maturity. Seeds ovoid, sarcotesta cream when immature, orange-brown when mature, sclerotesta beige, $2.3-2.7 \mathrm{~cm}$ diameter, $1.6-1.9 \mathrm{~cm}$ long, with micropylar ridges.

Habitat description: Ceratozamia aurantiaca grows in karst tropical forests or PinusQuercus forests, between 200 to $800 \mathrm{~m}$ a.s.l.

Etymology: The specific epithet is from the Latin "aurantiacus" and refers to the glowing orange color of emerging leaves.

\section{Discussion}

Ceratozamia aurantiaca possesses a set of diagnosable traits that separates it from its congeners with which it might be confused: orange emergent leaves, shorter petioles, wider median leaflets, and wider spacing between median leaflets. It also possesses a suite of additional traits that, combined with the above-mentioned traits and taken as a whole, distinguish it from all other species in the genus: leaves ascending, with numerous robust, large, medium, and small, recurved to barbed, green prickles on the petiole; coriaceous, leaflets lanceolate in shape, symmetrical to slightly asymmetrical, linear to subfalcate (occasionally slightly sigmoid), with wide articulations; large megasporangiate strobilus with orange base color, green coloration localized to the terminal facet of the megasporophylls, and numerous dark trichomes.

The distinction of Ceratozamia aurantiaca as a new species helps resolve the definition of C. robusta. Historically, all populations sharing characteristics of the C. robusta species complex (large trunks, large cones, and large leaves with prickled petioles) from Chiapas, Belize, Guatemala, and Oaxaca were assumed to be C. robusta. However, recent studies $[7,9,10]$ have suggested that $C$. robusta, as defined by the neotypification by Stevenson \& Sabato [6], seems to be restricted to the eastern portion of the distributional range (Chiapas, Belize, and Guatemala), whereas the populations from Oaxaca and Guerrero might represent a group of closely related species. Ceratozamia leptoceras seems to be the most dissimilar when compared with the species covered in this study (Table 2), as it has thin prickles on the petioles (thick in the other species), linear leaflets with membranaceous texture (lanceolate and papyraceous or coriaceous in the other species), and an acute megastrobilus apex (acuminate or mucronate in other species).

The species comprising the $C$. robusta species complex occur in mesic habitats, usually rainforests considered floristic refugia during the Neogene glaciations [13]. Such areas are currently separated by drier valleys or high mountains that may represent geographic barriers against gene flow (Figure 1). These patterns of distribution suggest that the Ceratozamia species are products of geographic isolation leading to allopatric speciation, as has been demonstrated in another cycad species in this geographic area [14]. After gaining geographic isolation, cycads seem to be prone to experience local adaptation through the retention/acquisition of anatomical features $[8,15]$ and stochastic, demographic processes $[14,16]$. Ceratozamia aurantiaca is likely to have originated through similar evolutionary processes.

Pigment variation in emerging leaves has been well documented in Ceratozamia. Whitelock [17] mentioned that emerging leaves in the species belonging to the Ceratozamia miqueliana species complex (e.g., C. miqueliana H.Wendl., C. euryphyllidia Vázq.Torres, Sabato \& D.W.Stev., C. becerrae Pérez-Farr., Vovides \& Schutzman) always produce lime-green emergent leaves, a trait that can be considered as diagnostic in this group. Other Ceratozamia species may also produce a brownish pigmentation that may vary from yellowish-brown (as in C. subroseophylla) to a more common reddish-brown color, as in C. sanchezae or C. robusta. In populations of these latter species, it is common to find individuals producing either green or reddish-brown emerging leaves. On the other hand, the northern species 
(e.g., C. latifolia Miq., C. zaragozae Medellín, C. chamberlainii Mart.-Domínguez, Nic.-Mor. \& D.W.Stev.) always produce emerging leaves of brownish to reddish color. The presence of the orange color in emerging leaves of $C$. aurantiaca is unique in the genus. This distinctive trait is present in wild plants (Figure 2) and in plants living in garden conditions for nearly 30 years (Figures A1 and A2), suggesting that it has a genetic background, rather than environmental. The fixed expression of pigments that produce the orange color in emerging leaves may be the result of stochastic, demographic processes (a combination of population bottlenecks and the random fixation of alleles due to genetic drift).

To date, three populations of Ceratozamia aurantiaca are known in the wild (Figure 1), in the municipalities of San Pedro Teutila and San Bartolomé Ayautla, Oaxaca. Populations have a narrow distribution and have suffered burning and clearing due to livestock activities. There are approximately 50 adult plants in San Bartolomé Ayautla, and close to 200 adult plants in San Pedro Teutila; thus, this species should be considered as "threatened with extinction" (P) in the Mexican Official Norm NOM-059-ECOL (SEMARNAT 2010) and as "Endangered" according to the IUCN Red List of Threatened Species (2021), based on the criteria A2ce+4c; C1. Further studies of more populations from Oaxaca and phylogenetic analyses at the genus level, as performed on other cycad genera in Mexico [18,19], will further clarify the species and genetic diversity in Ceratozamia, the delimitation within the C. robusta species complex, and the evolutionary history of the cycad genus Ceratozamia.

Author Contributions: Conceptualization, M.A.P.-F. and J.S.G.-O.; methodology, M.A.P.-F., J.S.G.O. and M.C.; software, J.S.G.-O.; validation, M.A.P.-F., J.S.G.-O., J.L.H., J.C., S.H.S.-M., M.C. and A.P.V.; formal analysis, J.S.G.-O.; investigation, M.A.P.-F., J.S.G.-O., J.L.H., J.C., S.H.S.-M., M.C. and A.P.V.; resources, M.A.P.-F., S.H.S.-M. and A.P.V.; data curation, J.S.G.-O.; writing-original draft preparation, M.A.P.-F., J.S.G.-O. and J.L.H.; writing-review and editing, M.A.P.-F., J.S.G.-O., J.L.H., J.C., S.H.S.-M., M.C. and A.P.V.; visualization, J.S.G.-O.; supervision, M.A.P.-F.; project administration, M.A.P.-F.; funding acquisition, M.A.P.-F. All authors have read and agreed to the published version of the manuscript.

Funding: Funding for this research was provided by the Montgomery Botanical Center through the Plant Exploration Fund and an anonymous donor.

Institutional Review Board Statement: Not applicable.

Informed Consent Statement: Not applicable.

Data Availability Statement: Not applicable.

Acknowledgments: We are dedicating this new species to two mutual friends who recently passed away. George Sparkman, cycad horticulturist, passed away on 5 June 2020. He had a passion for cycads and loved to share it with others. John Rees, geographer and one of the pioneers of the study of cycad biology in Mexico, passed away in late July 2021. We owe much of our knowledge about the cycad populations to his contributions. They are greatly missed. The authors thank José García González for providing photos of the strobili, and Alexis Fabian José, Pedro Díaz Jiménez, and Héctor Gómez Domínguez for their support during fieldwork. Thanks to Gonzalo Juárez García (SERBO), César Chávez Rendón (Ethnobotanical Garden of Oaxaca) and Dávid Álvarez Guzmán from the community in Teutila, Oaxaca, for their support in fieldwork. Thanks to INECOL A.C. for providing vehicles for one of the field excursions.

Conflicts of Interest: The authors declare no conflict of interest. 


\section{Appendix A}
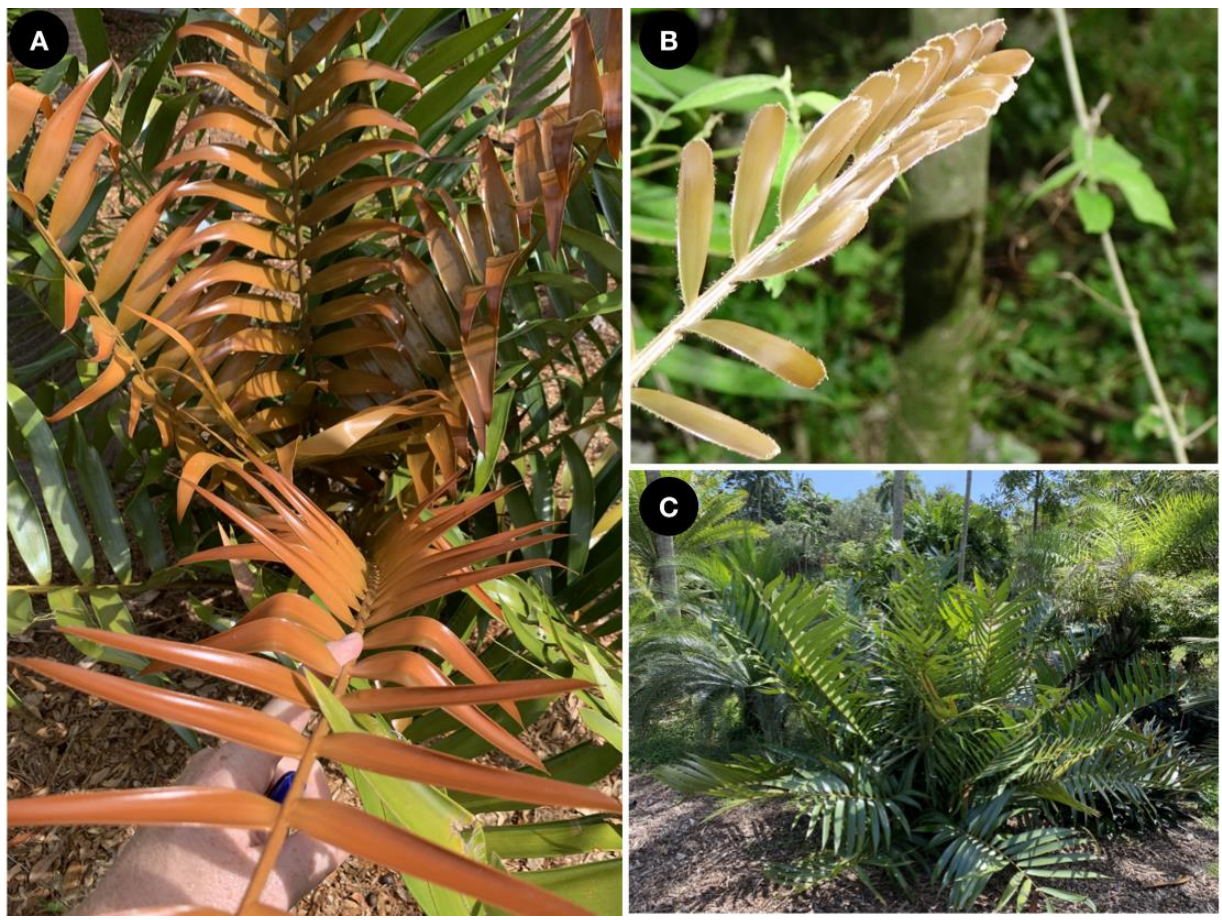

Figure A1. Leaf color variation in plants of Ceratozamia aurantiaca sp. nov. deposited in the Fairchild Tropical Botanic Garden, FL, USA. (A) Orange color in emerging leaves of adult plant. (B) Brown coloration in early stage of leaf emergence. (C) Adult plant with mature leaves.
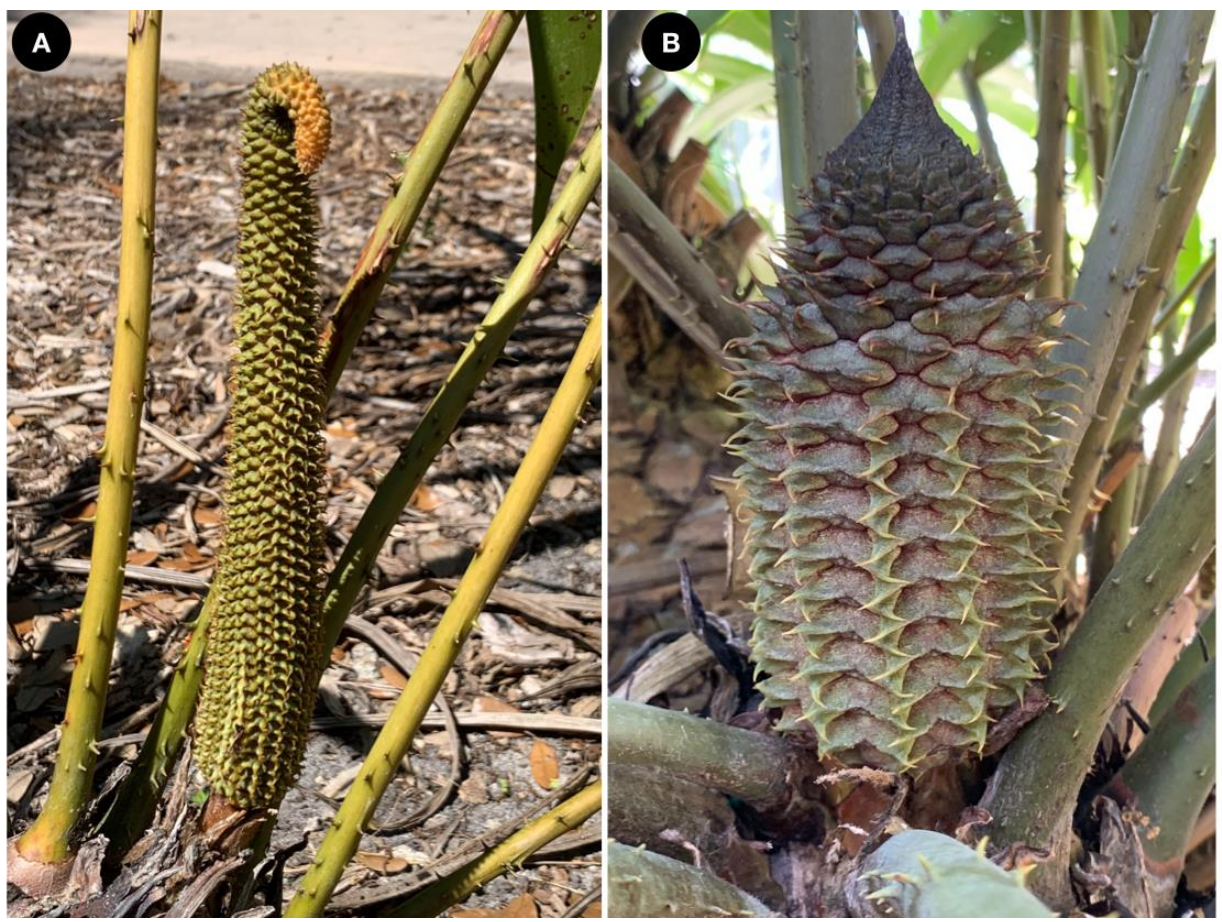

Figure A2. Mature microstrobilus (A) and immature megastrobilus (B) of Ceratozamia aurantiaca sp. nov. at Fairchild Tropical Botanic Garden, FL, USA. 


\section{References}

1. Calonje, M.; Stevenson, D.W.; Osborne, R. The World List of Cycads, Online Edition. 2021. Available online: http://www. cycadlist.org (accessed on 4 August 2021).

2. Vovides, A.P.; Pérez-Farrera, M.A.; González, D.; Avendaño, S. Relationships and Phytogeography in Ceratozamia (Zamiaceae). In Cycad Classification: Concepts and Recommendations; Walters, T., Osborne, R., Eds.; CABI Publishing: Wallingford, UK, 2004; pp. 109-125. [CrossRef]

3. Medina-Villarreal, A.; González-Astorga, J.; de Los Monteros, A.E. Evolution of Ceratozamia cycads: A proximate-ultimate approach. Mol. Phylogen. Evol. 2019, 139, 106530. [CrossRef] [PubMed]

4. Walters, T.; Osborne, R.; Decker, D. 'We Hold These Truths ... '. In Cycad Classification: Concepts and Recommendations; Walters, T., Osborne, R., Eds.; CABI Publishing: Cambridge, UK, 2004; pp. 1-11. [CrossRef]

5. Whitelock, L.M. The Cycads; Timber Press: Portland, OR, USA, 2002; p. 532.

6. Stevenson, D.W.; Sabato, S. Typification of names in Ceratozamia Brongn., Dion Lindl., and Microcycas A. DC. (Zamiaceae). Taxon 1986, 35, 578-584. [CrossRef]

7. Martínez-Domínguez, L.; Nicolalde-Morejón, F.; Vergara-Silva, F.; Stevenson, D.W. Integrative taxonomy of Mexican cycads: Biogeography, morphology and DNA barcoding corroborate a new sympatric species in Ceratozamia (Zamiaceae). Phytotaxa 2016, 268, 25-45. [CrossRef]

8. Vovides, A.P.; Pérez-Farrera, M.A.; Gutiérrez-Ortega, J.S.; Avendaño, S.; Medina-Villarreal, A.; González-Astorga, J.; Galicia, S. A revision of the Ceratozamia miqueliana (Zamiaceae) species complex based on analyses of leaflet anatomical characters. Flora 2020, 270, 151649. [CrossRef]

9. Martínez-Domínguez, L.; Nicolalde-Morejón, F.; Lorea-Hernández, F.G.; Vergara-Silva, F.; Stevenson, D.W. A novelty in Ceratozamia (Zamiaceae, Cycadales) from the Sierra Madre del Sur, Mexico: Biogeographic and morphological patterns, DNA barcoding and phenology. PhytoKeys 2020, 156, 1. [CrossRef] [PubMed]

10. Gutiérrez-Ortega, J.S.; Pérez-Farrera, M.A.; Vovides, A.P.; Chávez-Cortázar, A.; López, S.; Santos-Hernández, N.G.; Ruíz-Roblero, S.K. Ceratozamia sanchezae (Zamiaceae): A new cycad species from Chiapas Highlands (Mexico). Phytotaxa 2021, 500, $201-216$. [CrossRef]

11. Pérez-Farrera, M.A.; Vovides, A.P.; Hernández-Sandoval, L.; González, D.; Martínez, M. A Morphometric Analysis of the Ceratozamia norstogii Complex (Zamiaceae). In Cycad Classification: Concepts and Recommendations; Walters, T., Osborne, R., Eds.; CABI Publishing: Wallingford, UK, 2004; pp. 127-136.

12. Hammer, $\varnothing . ;$ Harper, D.A.; Ryan, P.D. PAST: Paleontological statistics software package for education and data analysis. Palaeontol. Electron. 2001, 4, 9.

13. Wendt, T. Las selvas de Uxpanapa, Veracruz-Oaxaca, México: Evidencia de refugios florísticos cenozoicos. An. Inst. Biol. UNAM Ser. Bot. 1989, 58, 29-54.

14. Gutiérrez-Ortega, J.S.; Salinas-Rodríguez, M.M.; Ito, T.; Pérez-Farrera, M.A.; Vovides, A.P.; Martínez, J.F.; Molina-Freaner, F.; Hernández-López, A.; Kawaguchi, L.; Nagano, A.J.; et al. Niche conservatism promotes speciation in cycads: The case of Dioon merolae (Zamiaceae) in Mexico. New Phytol. 2020, 227, 1872-1884. [CrossRef] [PubMed]

15. Gutiérrez-Ortega, J.S.; Yamamoto, T.; Vovides, A.P.; Pérez-Farrera, M.A.; Martínez, J.F.; Molina-Freaner, F.; Watano, Y.; Kajita, T. Aridification as a driver of biodiversity: A case study for the cycad genus Dioon (Zamiaceae). Ann. Bot. 2018, 121, 47-60. [CrossRef] [PubMed]

16. Gutiérrez-Ortega, J.S.; Molina-Freaner, F.; Martínez, J.F.; Pérez-Farrera, M.A.; Vovides, A.P.; Hernández-López, A.; Tezuka, A.; Nagano, A.J.; Watano, Y.; Takahashi, Y.; et al. Speciation along a latitudinal gradient: The origin of the Neotropical cycad sister pair Dioon sonorense-D. vovidesii (Zamiaceae). Ecol. Evol. 2021, 11, 6962-6976. [CrossRef]

17. Whitelock, L.M. Range and variation in the genus Ceratozamia (Zamiaceae). Bot. Rev. 2004, 70, 235-239. [CrossRef]

18. Calonje, M.; Meerow, A.W.; Griffith, M.P.; Salas-Leiva, D.; Vovides, A.P.; Coiro, M.; Francisco-Ortega, J. A time-calibrated species tree phylogeny of the New World cycad genus Zamia L. (Zamiaceae, Cycadales). Int. J. Plant Sci. 2019, 180, 286-314. [CrossRef]

19. Gutiérrez-Ortega, J.S.; Salinas-Rodríguez, M.M.; Martínez, J.F.; Molina-Freaner, F.; Pérez-Farrera, M.A.; Vovides, A.P.; Matsuki, Y.; Suyama, Y.; Ohsawa, T.A.; Watano, Y.; et al. The phylogeography of the cycad genus Dioon (Zamiaceae) clarifies its Cenozoic expansion and diversification in the Mexican transition zone. Ann. Bot. 2018, 121, 535-548. [CrossRef] 